\title{
Analysis of Swamp Microalgal Isolates from South Sumatra as Biofuel Candidates
}

Didi Jaya Santri ${ }^{1,2}$, Hilda Zulkifli ${ }^{2}$, Aldes Lesbani ${ }^{3}$, Hermansyah $^{3 *}$, Yenny Anwar ${ }^{1}$, Ermayanti $^{1}$, Vita Meylani ${ }^{4}$, Ahmad $^{2}$ Fudholi5,6

${ }^{1}$ Department of Biology Education, Faculty of Education and Teacher Training, Universitas Sriwijaya, Palembang 30662, Indonesia

${ }^{2}$ Department of Biology, Faculty of Mathematics and Natural Sciences, Universitas Sriwijaya, Palembang 30662, Indonesia

${ }^{3}$ Department of Chemistry, Faculty of Mathematics and Natural Sciences, Universitas Sriwijaya, Palembang 30662, Indonesia

${ }^{4}$ Department of Biology Education, Faculty of Education and Teacher Training, Universitas Siliwangi, Tasikmalaya 46115, Indonesia

${ }^{5}$ Solar Energy Research Institute, Universiti Kebangsaan Malaysia, Bangi Selangor 43600, Malaysia

${ }^{6}$ Research Centre for Electrical Power and Mechatronics, National Research and Innovation Agency (BRIN), Bandung 40135, Indonesia

Corresponding Author Email: hermansyah@unsri.ac.id

https://doi.org/10.18280/ijdne.160602

Received: 20 September 2021

Accepted: 19 November 2021

\section{Keywords:}

microalgae, swamp, biofuel, chlorella vulgaris

Beyerinck, lipid

\begin{abstract}
Microalgal isolates in various habitats have different biocomponents, and isolates found in the swamps of South Sumatra have not been explored deeply. This study was designed to analyse morphologically and isolate microalgae that have potential as biofuel candidates through their lipid content. Results showed that five isolates originating from four different sources in South Sumatra, namely, Chlorella vulgaris Beyerinck (DV 005), Dictyosphaerium granulatum Hindák (DV 003), Nannochloropsis sp. (DV 009), Scenedesmus bernardii G. M. Smith (DV 011) and Golenkinia radiata Chodat (DV 001), were identified. Amongs the five isolates, the $C$. vulgaris Beyerinck (DV 005) isolate had the highest lipid content $(15.30 \%)$, indicating its potential as biofuel candidate.
\end{abstract}

\section{INTRODUCTION}

The increasing number of human populations is in line with the increasing needs of human life, e.g., fuel [1]. For almost a century, humans have been highly dependent on fossil fuels [2], causing the world economy to increase. However, this increase is inversely proportional to environmental conditions that are increasingly being degraded and experiencing a decrease in quality. This phenomenon can be seen by the increasing number of greenhouse gas (GHG) emissions [3] which continue to accumulate in the atmosphere and impact climate change. In addition, the result of the analysis of $\mathrm{CO}_{2}$ levels in the current era shows extremely high concentrations in the last 800,000 years [4]. Fossil energy sources that are difficult to renew are also decreasing in number. This phenomenon has a negative impact on the conditions of the earth. However, sustainable sources of biofuels have reduced the world's dependence on fossil fuels due to low GHG emissions, low impact on the environment and high energy security $[5,6]$. Therefore, humans need to maximise the potential of biofuels that are environmentally friendly and easily renewable.

Many biofuels have been produced from edible raw materials, such as corn, sugar cane and vegetable oil [6]. These materials are abundant in nature but have high initial treatment costs and are not economically feasible. Sustainable sources of biofuels are highly needed to overcome this challenge $[6,7]$. Microalgae are abundant in nature, can reproduce quickly and have excellent adaptability to unfavourable environmental conditions $[8,9]$. These characteristics support microalgae as potential renewable biofuels [10-12]. In addition, the contents of triglycerides and polysaccharides in microalgae are highly suitable for use as biofuels [12]. Microalgae have content that can be modified on the basis of humans' needs by utilising the growth medium [13, 14]. Biofuel from microalgae is also environmentally friendly, free from pollution and cheap, making it an alternative fuel that is feasible for development [15]. Various biofuels can be produced from microalgal biomass, such as biodiesel (lipid-based), bioethanol (carbohydrate-based) and high-level alcohols (protein-based) [16]. Therefore, microalgae may be used as an alternative biofuel.

Microalgae include various groups of organisms that can be classified into several classes, such as cyanobacteria (Cyanophyceae), green algae (Chlorophyceae), diatoms (Bacillariophyceae), yellow-green algae (Xantophyceae), golden algae (Chrysophyceae), red algae (Rhodophyceae), brown algae (Phaeophyceae), dinoflagellates (Dinophyceae) and picoplankton (Prasinophyceae and Eustigmatophyceae) [17-19]. Microalgal growth depends on the presence of light intensity, temperature, nutrient concentration, salinity and $\mathrm{pH}$ [20]. Environmental factors at different locations can significantly affect the diversity of microalgae and their growth rates. For this reason, microalgae should be screened and isolated to produce high biomass and biocomponent contents in specific habitats [21]. Microalgae with high biocomponent content and growth in their natural habitat need to be investigated as biofuel candidates [22]. Algal biomass has the potential to be converted into biofuel by use of the thermochemical or biological methods, yielding a $\mathrm{CO}_{2}$-neutral 
energy carrier comparable to biofuels produced from other biomass sources [23]. South Sumatra Province has a large swamp area of about 613795 ha consisting of 455949 ha of tidal swamp and 157846 ha of lowland swamp, thereby indicating its high microalgae potential [24]. Swamps have acidic $\mathrm{pH}(4-4.5)$ and are characterised by high contents of clay and silt fractions. Furthermore, the sand fraction is low and contains a lot of $\mathrm{Ca}$ and $\mathrm{Mg}$ and a little $\mathrm{K}$ and $\mathrm{Na}$ [25].

However, the isolation of microalgae from the natural environment of various swamp habitats in South Sumatra has not been explored. Therefore, this study is designed to analyse and isolate microalgae that are potential biofuel candidates through their lipid content. This research can be used as a reference to dig deeper into microalgae isolates from swamps that have the potential to be candidates for biofuels.

\section{MATERIAL AND METHODS}

\subsection{Sampling method}

Sampling was carried out at several water locations in South Sumatra, namely, Palembang, Banyuasin, Ogan Ilir and Ogan Komering Ilir. The four of sampling location are the representative swamps in South Sumatera has not been explored. Each sampling location was determined by its coordinates by using GPS (Figure 1).

At each sampling location, physical and chemical factors of the aquatic environment were evaluated by determining $\mathrm{pH}$ levels, temperature, dissolved oxygen levels, turbidity, total dissolved solids and total suspended solids in situ [26]. Samples were collected in the morning between 08:00 and 11:00 from the top and bottom of the waters by using a plankton net compositely to obtain the dominant microalgae in every level. Furthermore, researchers conducted water sampling by using a 10 liter bucket. The collected water was then filtered 10 times with a plankton net. Afterwards, each $100 \mathrm{ml}$ sample was collected in a bottle and subjected to lowtemperature conditions in the laboratory. The label of each sample bottle contained the following information: name of the observation location, day, date and time of sampling.

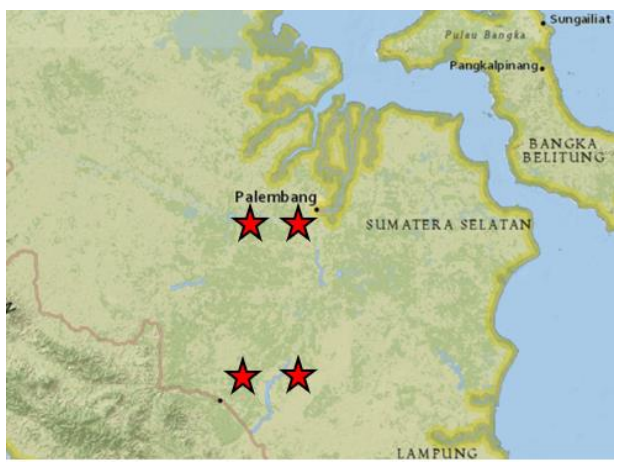

Figure 1. Map of South Sumatra swamps

\subsection{Microalgal abundance}

The abundance of microalgae was calculated by counting the number of microalgal cells by using the Sedgwick Rafter Counting Cell through the hand counting method. The Sedgwick Rafter Counting Cell was cleaned first. Afterwards, the water sample to be calculated for density was dripped as much as $1 \mathrm{ml}$. The sample was added with one drop of gelatine to slow down the movement of microalgae and closed with a cover glass. Furthermore, the Sedgewick Rafter Counting Cell was observed under a microscope, and the number in each box was calculated using the hand counting method [27].

\subsection{Microalgal biomass isolation and cultivation}

The isolation and cultivation of microalgae aimed to obtain potential biomass as a source of biofuel and were carried out in a laboratory scale (batch culture). The isolation and propagation of isolates were conducted with agar and liquid culture media. The isolates were then propagated using culture flasks in the laboratory by using microalgal culture media (BBM and BG11). The isolation and cultivation process applied in this study followed the procedure used by Lee et al. $[26,28]$. Isolation was carried out to separate the algal population and obtain a single type of algae from water samples by using the standard plating method. Samples from the field were serially diluted to facilitate the isolation process. The agar medium $(40 \mathrm{ml})$ was poured into a sterile Petri dish and used as growth medium for the thawed sample.

The sample liquid $(1 \mathrm{ml})$ was flattened onto the surface of the agar medium. Researchers transferred the microalgal colonies into sterile media in Petri dishes, which were incubated at room temperature $\left(20^{\circ} \mathrm{C}-25^{\circ} \mathrm{C}\right)$ for 14 days until the algae grew. This process was repeated to obtain microalgal unicells. Diluted microalgal cells resulted in low likelihood of bacterial contamination. Grown algal cultures were then separated in various growth media under sterile conditions and placed at room temperature in the laboratory. This step was repeated until a single culture of algae was obtained. Stock cultures were maintained once a month by regrowing on agar media. The result of this stage was pure isolates of local microalgae, which were obtained from fresh waters in South Sumatra.

Cells were transferred into dilute media in culture tubes, placed in the culture bottle under low light at an appropriate constant temperature and checked microscopically for growth or waited until macroscopic growth could be detected (3-4 weeks after transfer). The isolates that grew were identified on the basis of the colony morphology found on the agar culture medium. A general classification method was carried out to differentiate the formation of colonies morphologically. Liquid culture results were identified through microscopic observations for cell morphology down to the genus level. Each isolate was labelled and photographed at different magnifications. Species identification was performed in accordance with the methods of the references [29-31].

\subsection{Morphological identification}

Phenotypic identification was carried out on the basis of morphological characteristics to determine the diversity of microalgal species. Algal morphology was observed using a specific microscope for microalgae. Identification was carried out by referring to the algal identification key as applied in several studies [29-31] and the online identification key from the Center for Freshwater Biology website [32]. Species diversity data were analysed descriptively and presented using the table of species composition based on the taxonomic rank.

\subsection{Lipid content analysis}

The analysis of total lipid content was carried out through 
the Bethien-Diemar (1963) method [33] by utilising nonpolar petroleum ether as solvent. The percentage of the total dry weight of lipids was calculated using Eq. (1):

$$
\% \text { total lipid }=\frac{(A-B)}{C} \times 100
$$

where, A is weight of flask + weight of lipid after extraction (mg), B is weight of flask before extraction (mg) and C is the dry weight of the sample.

\section{RESULTS}

The collected microalgae were those found at the top and bottom layers of the waters by using a plankton net compositely. The results of the isolation can be seen in Table 1.

The identification of microalgal isolates was carried out specifically and carefully on the basis of their morphological characteristics to obtain five species representing four different sampling locations in South Sumatra (Table 2). Isolates from four location showed that the most numerous isolates are from Palembang and the least is from Ogan
Kemiring Ilir. Isolates from Palembang also very various genus that we found, and it can be like a control in this research. Because the various genus in others location is same with some of the genus from Palembang. From four locations, there are 2 genus (Anabaenopsis and Phacus) from Banyuasin are different from the genus that we found from Palembang as a control location.

From all of the genus that we found, there are five isolates has identification until species level. Based on the results of the identification of microalgal isolates carried out and correlated with taxonomic information, two isolates (i.e., Chlorella vulgaris Beyerinck and Dictyosphaerium granulatum Hindák) belonged to Trebouxiophyceae, and three isolates (i.e., Nannochloropsis sp., Scenedesmus bernardii G. M. Smith and Golenkinia radiata Chodat) belonged to Chlorophyceae. These results indicated that the microalgal isolates found in South Sumatra were dominated by Chlorophyceae.

The morphological of five microalgal isolates from Palembang, Ogan Ilir, Banyuasin, and Ogan Kemriing Ilir (Figure 2).

Figure 3 shows that amongst the five isolates identified and analysed for their lipid content, $C$. vulgaris Beyerinck isolates had the highest potential to be a candidate for biofuel.

Table 1. Microalgal isolates from swamps in several locations in South Sumatra

\begin{tabular}{ccccc}
\hline Origin of sample & & \multicolumn{2}{c}{ Genus } & \\
\hline & Actinastrum & Eudorina & Monoraphidium & Scenedesmus \\
& Ankistrodesmus & Euglena & Mougeotia & Selenastrum \\
& Aphanothece & Eugtimatos & Navicula & Spirogyra \\
& Chlamydomonas & Golenkenia & Nitzschia & Spirulina \\
Palembang & Chlorella & Gomphosphaeria & Oocystis & Staurastrum \\
& Coelastrum & Marssoniella & Oscillatoria & Tabellaria \\
& Cosmarium & Merismopedia & Pandorina & Tetraedon \\
& Desmidium & Micractinium & Pediastrum & Tetrastrum \\
& Dictyosphaerium & Microcyistis & Pyrobotrys & Zygnema \\
& Actinastrum & Chlorella & Microcystis & Oscillatoria \\
Banyuasin & Anabaenopsis & Euglena & Monoraphidium & Phacus \\
& Aphanothece & Merismopedia & Nitzschia & Scenedesmus \\
& Ankistrodesmus & Monoraphidium & Scenedesmus & Straurastrum \\
Ogan Ilir & Dictyospharium & Pediastrum & Selenastrum & \\
Ogan Kemiring Ilir & Scenedesmus & Nitchzia & & \\
\hline
\end{tabular}

Table 2. The potential microalgal as candidate biofuels from swamps in various locations in South Sumatra

\begin{tabular}{cccc}
\hline No & Isolate Code & Name of Species & Origin \\
\hline 1 & DV 005 & Chlorella vulgaris Beyerinck & Palembang \\
2 & DV 003 & Dictyosphaerium granulatum Hindák & Palembang \\
3 & DV 011 & Scenedesmus bernardii G. M. Smith & Banyuasin \\
4 & DV 009 & Nannochloropsis sp. & Ogan Ilir \\
5 & DV 001 & Golenkinia radiata Chodat & Ogan Komering Ilir \\
\hline
\end{tabular}

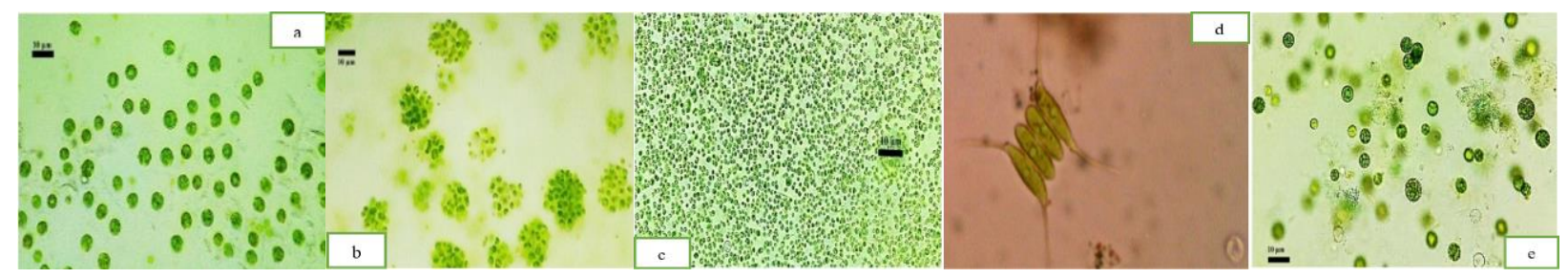

Figure 2. Morphological appearance

a. Chlorella vulgaris Beyerinck, b. Dictyosphaerium granulatum Hindák, c. Nannochloropsis sp., d. Scenedesmus Bernardii G. M. Smith and e. Golenkinia radiata Chodat found in swamp areas in South Sumatra (magnification $=400 \times$, bar scale $=10 \mu \mathrm{m}$ ) 


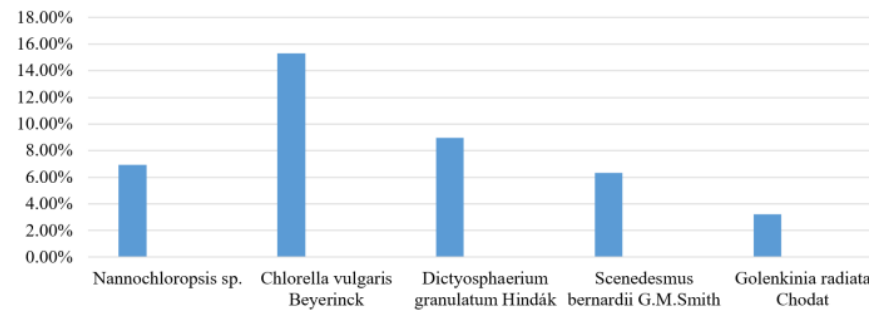

Figure 3. Lipid content percentage in each microalgal isolate

\section{DISCUSSION}

\subsection{Swamp microalgae survey and isolation}

Based on the results of the isolation in Table 1, most of the isolates come from Palembang, showing that the swamp area in Palembang is rich in minerals needed by microalgae naturally. The growth of microalgae in nature is strongly influenced by environmental factors, such as light intensity, temperature, $\mathrm{pH}$ and nutrients [34]. A high diversity of microalgal genera at swamps in Palembang compared with those in other locations is presumed to be because the swamp areas of sampling locations in Palembang contain a variety of different minerals needed by microalgae to grow, such as N, P, $\mathrm{K}, \mathrm{Mg}, \mathrm{S}$ and $\mathrm{H}$ [35]. A previous study also found that the waters of Palembang have six types of microalgae, namely, Microcystis aeruginosa, Nannochloropsis oculata, Oscillatoria sp., G. radiata, Dictyospherium pulchellum and C. vulgaris [36]. In the fresh waters of Banyuasin, a previous study only found four species, namely, $C$. vulgaris, Scenedesmus obliqus, Nannochloropsis oculata and Ankistrodesmus falcatus [37]. These results indicate that the diversity of microalgae in South Sumatra especially in Palembang is high.

\subsection{Identification of swamp microalgal morphology}

The dominance of Chlorophyceae is presumed because this group has high adaptability especially in freshwater in solitary and in colonies [38]. The results of the morphological identification of the microalgal isolates are described in Figure 1. Morphologically, C. vulgaris Beyerinck isolates have the following characteristics: (i) round or ovoid cells, (ii) unicellular, (iii) size of $10 \mu \mathrm{m}$, (iv) dominance of green colour, (v) chloroplasts and pyrenoids [39] and (vi) hard cell walls because of cellulose and pectin [40]. C. vulgaris Beyerinck can live at an optimum salinity of 10-20 ppt and can still live at $40^{\circ} \mathrm{C}$ [40]. In addition, C. vulgaris Beyerinck can live in solitary or in colonies [40]. D. granulatum Hindák isolates have the following characteristics: (i) round colonies, (ii) many cells (4-64 cells), (iii) mucus-like mass covering, (iv) cell colony size of about $33.75 \mu \mathrm{m}$, (v) green colour, (vi) round cell with a size of 3-5 $\mu \mathrm{m}$ and (vii) chloroplasts with pyrenoids [39]. Nannochloropsis sp. isolates have the following characteristics: (i) unicellular; (ii) round cell; (iii) size of about $3.5 \mu \mathrm{m}$; (iv) dominance of the colour of the chloroplast pigment, i.e. yellowish green [39]; (v) cell walls, mitochondria, chloroplasts and membrane-enclosed nucleus and (vi) bell-shaped chloroplasts located at the edge of the cell, a light-sensitive stigma (eyespot) and cell walls made of cellulose components, which are distinct characteristics of this microalga [41, 42]. Furthermore, Nannochloropsis sp. is cosmopolitan in nature and can be found in almost all types of water, e.g. marine and freshwaters. Nannochloropsis sp. can grow at high salinity. In addition, the optimum condition for its growth is $25 \%-35 \%$ and optimal temperature range of $25^{\circ} \mathrm{C}-30^{\circ} \mathrm{C}[43,44]$. S. bernardii G. M. Smith isolates have the following characteristics: (i) cells with cylindrical forms (sometimes elliptical or crescent-shaped forms), (ii) colonial nature with 4-16 cells attached to the centre side by side to form flattened colonies, (iii) long spinelike structures at both ends of each cell and (iv) cell length of $30 \mu \mathrm{m}$ and width of about $5 \mu \mathrm{m}$ [39]. G. radiata Chodat isolates have the following characteristics: (i) round shape, (ii) cilia on the cell surface, (iii) size of $15.25 \mu \mathrm{m}$ and (iv) green colour [39]. Although identification results show that the isolates obtained from the swamps of South Sumatra are members of the Chlorophyceae group, each isolate has its respective morphological characteristics.

\subsection{Analysis of lipid content of microalgae from swamp areas in south Sumatra}

The analysis of lipid content is one indicator to determine the potential of microalgae as a candidate for biofuel. This analysis was carried out using the Bethien-Diemar (1963) method (in Endrawati, 2012 [33]). The results of the analysis indicate that the highest percentage is found in the $\mathrm{C}$. vulgaris Beyerinck isolate (Figure 2). Pratono et al. indicated that $\mathrm{C}$. vulgaris Beyerinck possesses $15.30 \%$ crude fat, which is exactly as that obtained in this study. Rebolloso-Fuentes et al. $[15,45,46]$ showed that Nannochloropsis sp. contains high lipids, i.e. around $31 \%-68 \%$. However, in the present study, only $6.94 \%$ lipid is found in Nannochloropsis sp. The results of the analysis also show that the G. radiata Chodat isolate has the lowest lipid content (3.21\%).

\section{CONCLUSION}

In this study, researchers obtained five isolates, which are morphologically identified as $C$. vulgaris Beyerinck (DV 005), D. granulatum Hindák (DV 003), Nannochloropsis sp. (DV 009), S. bernardii G. M. Smith (DV 011) and G. radiata Chodat (DV 001). The highest lipid content is found in $C$. vulgaris Beyerinck (DV 005) isolates, which are presumed to have potential for use as a candidate for biofuel. This research can be used as a reference to dig deeper into microalgae isolates from swamps that have the potential to be candidates for biofuels.

\section{REFERENCES}

[1] Zou, C., Zhao, Q., Zhang, G., Xiong, B. (2016). Energy revolution: Froma fossil energy era to a new energy era. Natural Gas Industry B, 3(1): 1-11. https://doi.org/10.1016/j.ngib.2016.02.001

[2] Deliismail, O., Ozdogru, B., Seker, E. (2018). Biofuel production from Nannochloropsis oculata microalgae in seawater without harvesting and dewatering over alumina-silicate supported nickel catalysts. Bioresource Technology Reports, 3: 205-210. https://doi.org/10.1016/j.biteb.2018.07.016

[3] Sankaran, R., Show, P.L., Nagarajan, D., Chang, J.S. (2018). Exploitation and biorefinery of microalgae. Waste Biorefinery Elsevier, 571-601. 
https://doi.org/10.1016/B978-0-444-63992-9.00019-7

[4] Lindsey, R. (2018). Climate Change: Atmospheric Carbon Dioxide. https://www.climate.gov/newsfeatures/understanding-climate/climate-changeatmospheric-carbon-dioxide.

[5] Salama, E.S., Kurade, M.B., Abou-Shanab, R.A.I., ElDalatony, M.M., Yang, I.S., Min, B., Jeon, B.H. (2017). Recent progress in microalgal biomass production coupled with wastewater treatment for biofuel generation. Renew Sust Energ Rev., 79: 1189-1211. https://doi.org/10.1016/j.rser.2017.05.091

[6] Arif, M., Bai, Y., Usman, M., Jalalah, M., Harraz, F.A., Al-Assiri, M.S., Li, X., Salama, E.S., Zhang, C. (2020). Highest accumulated microalgal lipids (polar and nonpolar) for biodiesel production with advanced wastewater treatment: Role of lipidomics. Bioresource Technology, 298:

122299

https://doi.org/10.1016/j.biortech.2019.122299

[7] Aditiya, H., Chong, W., Mahlia, T., Sebayang, A., Berawi, M., Nur, H. (2016). Second generation bioethanol potential from selected Malaysia's biodiversity biomasses: A review. Waste Manag., 47: 4661. https://doi.org/10.1016/j.wasman.2015.07.031

[8] Adeniyi, O.M., Azimov, U., Burluka, A. (2018). Algae biofuel: Current status and future applications. Renew Sustain Energy Rev, 90: 316-335. https://doi.org/10.1016/J.RSER.2018.03.067

[9] Rittmann, B.E. (2008). Opportunities for renewable bioenergy using microorganisms. Biotechnol. Bioeng., 100: 203-212. https://doi.org/10.1002/bit.21875

[10] Deliismail, O., Ozdogru, B., Seker, E. (2018). Biofuel production from Nannochloropsis oculata microalgae in seawater without harvesting and dewatering over alumina-silicate supported nickel catalysts. Bioresource Technology Reports, 3: 205-210. https://doi.org/10.1016/j.biteb.2018.07.016

[11] Khanna, P., Kaur, A., Goyal, D. (2019). Algae-based metallic nanoparticles: Synthesis, characterization and applications. Journal of Microbiological Methods, 163: 105656. https://doi.org/10.1016/j.mimet.2019.105656

[12] Vignesh, N.S., Vimali, E., Sangeetha, R., Arumugam, M., Ashokkumar, B., Ganeshmoorthy, I., Varalakshmi, P. (2020). Sustainable biofuel from microalgae: Application of lignocellulosic wastes and bio-iron nanoparticle for biodiesel production. Fuel, 278: 118326. https://doi.org/10.1016/j.fuel.2020.118326

[13] Meher, L.C., Sagar, V.D., Naik, S.N. (2006). Technical aspects of biodiesel production bytransesterification-a review. Renew. Sust. Energ. Rev., 10: 248-268. https://doi.org/10.1016/j.rser.2004.09.002

[14] Leong, W.H., Lim, J.W., Lam, M.K., Uemura, Y., Ho, Y.C. (2018). Third generation biofuels: Anutritional perspective in enhancing microbial lipid production Renew Sustain Energy Rev., 91: 950-961. https://doi.org/10.1016/J.RSER.2018.04.066

[15] Chisti, Y. (2007). Biodiesel from microalgae. Biotechnology Advances, 25(3): 294-306. https://doi.org/10.1016/j.biotechadv.2007.02.001

[16] Staples, M.D., Malina, R., Barrett, S.R. (2017). The limits of bioenergy for mitigating global life-cycle greenhouse gas emissions from fossil fuels. Nat Energy, 2: 16202. https://doi.org/10.1038/nenergy.2016.202

[17] Venkatesan, J., Manivasagan, P., Kim, S.K. (2015). Marine microalgae biotechnology: Present trends and future advances. In Handbook of Marine Microalgae, Academic Press, pp. 1-9. https://doi.org/10.1016/B9780-12-800776-1.00001-7

[18] Zhu, L.D., Hiltunen, E., Antila, E., Zhong, J.J., Yuan, Z.H., Wang, Z.M. (2014). Microalgal biofuels: Flexible bioenergies for sustainable development. Renewable and Sustainable Energy Reviews, 30: 1035-1046. https://doi.org/10.1016/j.rser.2013.11.003

[19] Suganya, T., Varman, M., Masjuki, H.H., Renganathan, S. (2016). Macroalgae and microalgae as a potential source for commercial applications along with biofuels production: A biorefinery approach. Renewable and Sustainable Energy Reviews, 55: 909-941. https://doi.org/10.1016/j.rser.2015.11.026

[20] Sayre, R. (2010). Microalgae: the potential for carbon $\begin{array}{lll}\text { capture. } & \text { Bioscience, } & \text { 60(9): }\end{array}$ https://doi.org/10.1525/bio.2010.60.9.9

[21] Shuba, E.S., Kifle, D. (2018). Microalgae to biofuels: 'Promising' alternative and renewable energy, review. Renewable and Sustainable Energy Reviews, 81(1): 743755. https://doi.org/10.1016/j.rser.2017. 08.042

[22] Hu, Q., Sommerfeld, M., Jarvis, E., Ghirardi, M., Posewitz, M., Seibert, M., Darzins, A. (2008). Microalgal triacylglycerols as feedstocks for biofuel production: perspectives and advances. Plant J, 54(4): 621-639. 313X.2008.03492.x

[23] Costa, J.A.V., De Morais, M.G. (2011). The role of biochemical engineering in the production of biofuels from microalgae. Bioresource Technology, 102(1): 2-9. https://doi.org/10.1016/j.biortech.2010.06.014

[24] Balai Besar Wilayah Sungai Wilayah Sumatera. (2017). https://sda.pu.go.id/profil/informasi_balai/balai_besar_ wilayah_sungai_sumatera_viii, accessed on 20 October 2021.

[25] Kodir, K.A., Juwita, Y., Arif, T. (2018). Inventarisasi dan karakteristik morfologi padi lokal lahan rawa di Sumatera Selatan. Buletin Plasma Nutfah, 22(2): 101108. http://dx.doi.org/10.21082/blpn.v24n2.2018.p77-82

[26] Lee, S.H., Oh, H.M., Jo, B.H., Lee, S.A., Shin, S.Y., Kim H.S., Lee, S.H., Ahn, C.Y. (2014). Higher biomass productivity of microalgae in an attached growth system, using wastewater. Journal of Microbiology and Biotechnology, 24(11): 1566-1573. http://dx.doi.org/10.4014/jmb.1406.06057

[27] Pachiappan, P., Prasath, B.B., Perumal, S., Ananth, S., Devi, A.S., Kumar, S.D., Jeyanthi, S. (2015). Isolation and culture of microalgae. In Advances in Marine and Brackishwater Aquaculture, Springer, New Delhi, pp. 115. https://doi.org/10.1007/978-81-322-2271-2_1

[28] Cho, S., Luong, T.T., Lee, D., Oh, Y.K., Lee, T. (2011). Reuse of effluent water from a municipal wastewater treatment plant in microalgae cultivation for biofuel production. Bioresource Technology, 102(18): 86398645. https://doi.org/10.1016/j.biortech.2011.03.037

[29] Bellinger, E.G., Sigee, D.C. (2010). Freshwater Algae Identification and Use as Bioindicators. John Wiley \& Sons, Ltd. Chichester, West Sussex, P019 8SQ, UK.

[30] Serediak, N., Huynh, M. (2011). Algae Identification Field Guide: An Illustrative Field Guide on Identifying Common Algae Found in the Canadian Prairies. Agriculture and Agri-Food Canada.

[31] Shayler, H.A., Siver, P.A. (2006). Key to freshwater algae: A web-based tool to enhance understanding of 
microscopic biodiversity. Journal of Science Education and Technology, 15(3-4): 298-303. https://doi.org/10.1007/s10956-006-9016-4

[32] http://cfb.unh.edu/phycokey/phycokey.htm, accessed on 20 October 2021.

[33] Endrawati, H., Manulang, C., Widianingsih, W. (2012). Densitas dan Kadar Total Lipid Mikroalga Spirulina platensis yang Dikultur pada Fotoperioda yang Berbeda. Buletin Oseanografi Marina, 1(3): 33-38. https://doi.org/10.14710/buloma.v1i3.6908

[34] Hadiyanto, Azim, M. (2012). Mikroalga Sumber Pangan dan Energi Masa Depan. Semarang: UPT UNDIP Press Semarang.

[35] Andersen, R.A. (2005). Algal Curturing Technique.UK: Elsevier Academic Press.

[36] Badriah, S.S. (2019). Isolasi Mikroalga dari Kolam Kota Palembang dan Sumbangannya terhadap Pembelajaran SMA. Skripsi. Indralaya: FKIP Unsri.

[37] Destriani, R.E. (2019). Isolasi Mikroalga dari Perairan Tawar Kabupaten Banyuasin dan Sumbangannya terhadap Pembelajaran Biologi SMA. Skripsi. Indralaya: FKIP Unsri.

[38] Sheehan, J., Dunahay, T., Benemann, J., Roessler, P. (1998). A Look Back at The U.S. Department of Energy's Aquatic Species Program; Biodiesel from Algae. Physics Today (Vol. 68). U.S: NREL.

[39] Guiry, M.D., Guiry, G.M. (2020). AlgaeBase. WorldWide Electronic Publication, National University of Ireland. http://www.algaebase.org.

[40] Merizawati. (2008). Analisis Sinar Merah, Hijau, dan
Biru (RGB) untuk Mengukur Kelimpahan Fitoplankon (Chlorella sp.). Fakultas Perikanan dan Ilmu Kelautan, Institut Pertanian Bogor. Bogor.

[41] Brown, M.R., Jeffrey, S.W., Volkman, J.K., Dunstan, G.A. (1997). Nutritional properties of microalgae for mariculture. $\quad 151(1-4)$ : https://doi.org/10.1016/S0044-8486(96)01501-3

[42] Sleigh, M.A. (1989). Protozoa and Other Protist. (E. Arnold, Ed.). London.

[43] Isnansetyo, A., Kurniastuty. (1995). Teknik Kultur Phytoplankton Zooplankton. Pakan Alam untuk Pembenihan Organism Laut. Yogyakarta: Kanisius.

[44] Razzak, S.A., Ilyas, M., Ali, S.A.M., Hossain, M.M. (2015). Effects of $\mathrm{CO}_{2}$ Concentration and $\mathrm{pH}$ on Mixotrophic Growth of Nannochloropsis oculata. Appl Biochem Biotechnol, 176(5): 1290-302. https://doi.org/10.1007/s12010-015-1646-7

[45] Rebolloso-Fuentes, M.M., Navarro-Pérez, A., GarcíaCamacho, F., Ramos-Miras, J.J., Guil-Guerrero, J.L. (2001). Biomass nutrient profiles of the microalga Nannochloropsis. Journal of Agricultural and Food Chemistry, 49(6): 2966-2972. https://doi.org/10.1021/jf0010376

[46] Nurhatika, S., Ermavitalini, D., Saputro, T.B., Apriyatmoko, Y. (2018). Biodiversity and characterization of high lipid content microalgae in Porong River Estuary East Java, Indonesia. Biodiversitas Journal of Biological Diversity, 19(2): 577-582. https://doi.org/10.13057/biodiv/d190234 